\title{
Workplace Charging: Charging Up University Campuses
}

Carrie Giles, ICF International

Carrie Ryder, ICF International

Stephen Lommele, National Renewable Energy Laboratory

March 2016

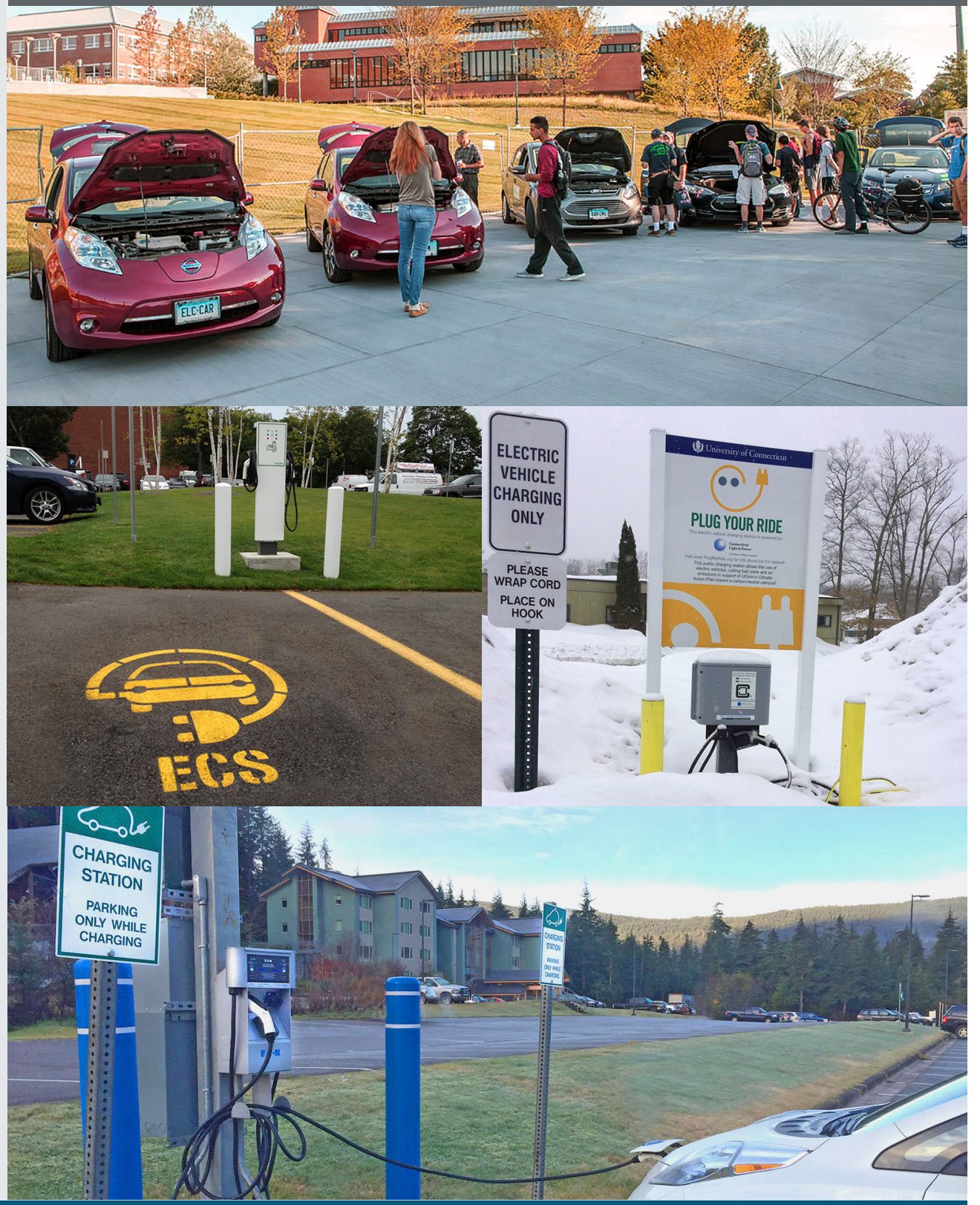




\section{Workplace Charging: Charging Up University Campuses}

As leading regional employers, colleges and universities are on the front line of local- and national-level technology trends. To remain competitive, many schools are offering plug-in electric vehicle (PEV) charging to their faculty, staff, and students.

While the installation and management of PEV charging stations requires planning, the U.S. Department of Energy (DOE) Workplace Charging Challenge, launched in 2013, aims to support these charging efforts. This document highlights the experiences of university partners in the Workplace Charging Challenge (Challenge) that demonstrate the many benefits charging provides to higher education institutions. PEV charging stations, known as electric vehicle supply equipment (EVSE), provide a service to employees and students, signal environmental

\section{Top 5 Reasons for Campus Charging:}

- $\quad$ Reduce commuter emissions

- Offer research opportunities

- Provide employee and student benefits

- Enable fleet charging

- Signal environmental leadership. leadership, deliver educational and research opportunities, and play an important role in achieving greenhouse gas (GHG) emissions reduction goals.

\section{Clean Commute}

Workplace charging at universities is an effective way to reduce a school's Scope $3^{1}$ emissions, which include emissions generated through employee commuting. Many universities have pledged to reduce GHG emissions either individually or through national pledges, such as the American College and University Presidents' Climate Commitment (ACUPCC). PEV charging stations are effective tools to help achieve these goals.

Reducing commuter emissions through workplace charging is particularly important on suburban, rural, and remote campuses with limited public transportation options. The University of North Carolina at Pembroke, located in Pembroke, North Carolina, joined the ACUPCC and pledged to become carbon neutral by 2050. In addition to offering a communal shuttle van, bicycle sharing program, Zipcars, and preferred parking for low-emissions, fuelefficient, and alternatively fueled vehicles, the University installed four PEV charging stations to reduce Scope 3 emissions and help achieve its goal of carbon neutrality. Learn more about the Emission Reduction Benefits of Workplace Charging.

\footnotetext{
${ }^{1}$ The World Resources Institute and World Business Council of Sustainable Development developed the Greenhouse Gas Protocol to set the global standard for how to measure, manage, and report GHG emissions. Indirect emissions are categorized as Scope 3 and include the extraction and production of purchased materials and fuels, transport-related activities in vehicles not owned by the reporting entity, outsourced activities, and other upstream and downstream emissions.
} 


\section{Academic Advantage}

PEV charging stations are a visible symbol of sustainability and environmental leadership, and they can help enrich a university's academics. Some schools have engineering students plan the installation of charging stations, while others task sustainability interns and students with creating charging advertising and management policies. In addition to formal curricula based around charging stations, the physical presence of charging stations sparks dialogue and encourages sustainability awareness among the student body.

Universities also play an important role in leading PEV and charging station research and development nationwide. For example, the University of California Los Angeles' Smart Grid Energy Research Center (SMERC) partners with utilities, government, policymakers, technology providers, PEV manufacturers, and other research laboratories and universities to investigate renewable energy and energy storage integration. SMERC provides employee charging as part of its research on integrating PEV into automated demand response microgrids.

\section{Campus Cooperation}

Because campuses need to support a variety of PEV users, from fleet managers and employees to students and community members, managing the charging stations usually involves multiple parties. The campus transportation department is often the administrator of charging stations initially installed for fleet-use, however on a single university campus there may be many different players. For example, parking services or campus security may manage use and access to stations, while the sustainability director may work with public relations and the president's office to advertise charging station availability and educate users about PEVs. Energy managers track energy usage, and facilities personnel often support the procurement and installation of charging stations. Academic departments, particularly those in engineering and sustainability, may also use the charging stations in their curriculum. The many players ensure that the charging stations are supported and used, but all parties must be engaged and consulted to ensure success-cooperation is key to building departmental relationships and managing campus charging. Learn more about how to administer a campus workplace charging program.

\section{Locations and Logistics}

When considering charging stations, there are a number of options available. For areas where users are expected to park for long periods-such as staff parking lots-Level 1, 120 volt (V) charging can work well. For areas with higher turnover, or more irregular parking schedules, faster Level 2, $240 \mathrm{~V}$ chargers may be more appropriate. Campuses need to consider the connectivity of chargers; while non-networked chargers lack subscription fees and are less expensive, networked chargers provide usage data that many schools find crucial in tracking emissions reductions and creating annual reports.

Some schools prefer to locate charging stations in secure parking garages, while others promote high visibility and access to all by placing them in prominent locations on campus. Schools should also plan for future campus expansion when considering where to locate 
charging stations. For example, if a surface lot may be affected by future construction, it may be prudent to locate charging stations in a permanent parking structure instead. Installing PEV charging infrastructure as part of current or future capital projects is a good way to avoid additional costs through expensive retrofits. The University of Massachusetts Lowell currently offers a network of PEV charging stations to its campus community and the public as part of its overall sustainability efforts. When the University decided to pursue PEV charging, it took a proactive approach with new parking facility construction, installing features such as conduit and expanded electrical capacity-making these facilities "PEV ready" and considerably reducing future charging station installation costs.

\section{Finances and Funding}

Due to budget restrictions, most colleges and universities turn to a variety of funding sources to finance all or part of their charging station installations. Potential funding sources can include research awards; private grants and donations; and municipal, state, federal, and utility incentives. Colleges and universities can collaborate with Clean Cities coalitions, local municipalities, and other organizations to provide charging on or near campus. Some state universities have also successfully received funding through legislation and state private-public partnerships. Many states offer rebates and grant programs for charging stations, some of which are specifically tailored to colleges and universities. The New York State Energy Research and Development Authority's (NYSERDA) Charge NY program has provided funding to support installation of PEV charging stations at many New York colleges and universities, including Clarkson University, State University of New York (SUNY) New Paltz, Purchase College $\underline{\text { SUNY, }}$ and Suffolk County Community College.

\section{Access and Availability}

Some public funding sources require recipients to make chargers accessible to the public in guest parking lots. However, if chargers are primarily intended for student- and employee-use only, there are a number of ways to limit public use. By placing chargers in secure parking structures, schools can limit physical access. Some schools, like Colorado State University, require that all PEV drivers register their vehicle as a PEV with the University's Parking and Transportation Services or pay for a daily or hourly permit before they can park and use campus charging stations. Other schools like North Central College in Naperville, Illinois, must first grant users access to their networked chargers. Regular users are provided with approved network accounts, and guests may register with the sustainability office for one-time access.

Based on a university's objectives, there are also a variety of ways to charge a fee for charging station use. Many schools offer free charging to employees and community members to encourage PEV adoption. To ensure the proper use of public funds, some public schools must charge a fee for the electricity consumed. Georgia Institute of Technology, for instance, charges users an hourly fee which increases after four hours, encouraging employees to move their charged vehicles and allow other users access. Learn more about fee-based and free charging, as well as charging station sharing best practices. 


\section{Publicity and Promotion}

Colleges and universities publicize their charging stations in a number of ways.

Station information is usually made available on a university's parking, transportation, and sustainability websites. For example, Harvard University's Campus Services department developed an informational video about its charging stations and posted it on a number of online channels. Many schools also provide charging station information to new employees through human resources departments. Others have hosted "ride and drive" events that connect the community with PEV drivers and local dealerships. In

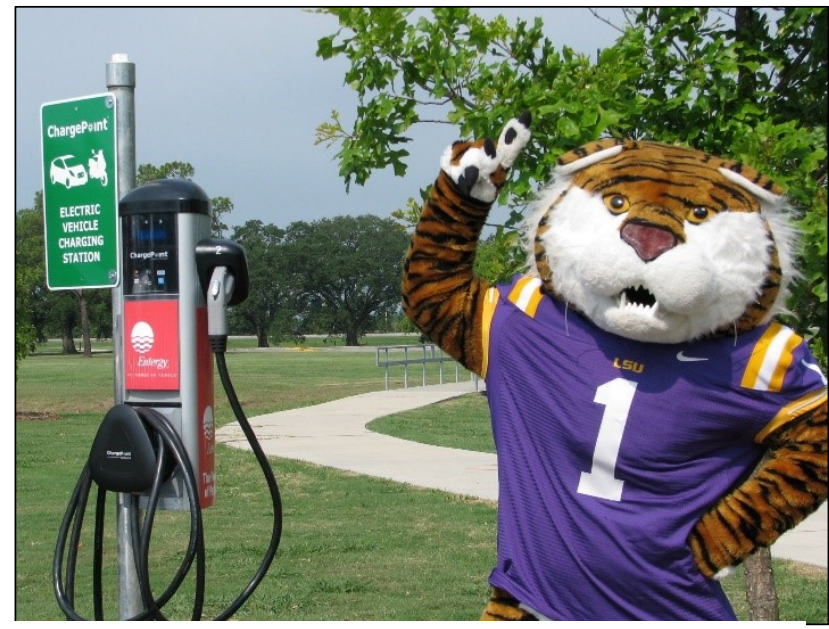

Charger installed on the Louisiana State University campus. Photo from Louisiana State University addition to providing employees and students with more information about PEVs, ride and drive events highlight a school's environmental leadership. Learn more about how to host a ride and drive, as well as how to educate employees about the benefits of driving electric.

Charging stations are a visible sign of a school's investment in sustainability. Some municipalities and states have developed recognition programs for organizations with PEV charging. Campus charging may help achieve goals related to national sustainability programs and green building certifications. DOE also draws attention to organizations that have displayed PEV leadership as partners in its Workplace Charging Challenge, a program that highlights employers that install EVSE for employee use. 


\title{
NOTICE
}

This report was prepared as an account of work sponsored by an agency of the United States government. Neither the United States government nor any agency thereof, nor any of their employees, makes any warranty, express or implied, or assumes any legal liability or responsibility for the accuracy, completeness, or usefulness of any information, apparatus, product, or process disclosed, or represents that its use would not infringe privately owned rights. Reference herein to any specific commercial product, process, or service by trade name, trademark, manufacturer, or otherwise does not necessarily constitute or imply its endorsement, recommendation, or favoring by the United States government or any agency thereof. The views and opinions of authors expressed herein do not necessarily state or reflect those of the United States government or any agency thereof.

This report is available at no cost from the National Renewable Energy Laboratory (NREL) at www.nrel.gov/publications.

Available electronically at SciTech Connect http://www.osti.gov/scitech

Available for a processing fee to U.S. Department of Energy and its contractors, in paper, from:

\author{
U.S. Department of Energy \\ Office of Scientific and Technical Information \\ P.O. Box 62 \\ Oak Ridge, TN 37831-0062 \\ OSTI http://www.osti.gov \\ Phone: 865.576.8401 \\ Fax: 865.576.5728 \\ Email: reports@osti.gov
}

Available for sale to the public, in paper, from:

\author{
U.S. Department of Commerce \\ National Technical Information Service \\ 5301 Shawnee Road \\ Alexandria, VA 22312 \\ NTIS http://www.ntis.gov \\ Phone: 800.553 .6847 or 703.605 .6000 \\ Fax: 703.605.6900 \\ Email: orders@ntis.gov
}




\section{U.S. Department of Energy's Workplace Charging Challenge}

In March 2011, President Obama announced the EV Everywhere Grand Challenge, which focuses on enabling U.S. companies to be the first in the world to produce PEVs that are as affordable and convenient for the average American family as a 2012 gasoline-powered vehicle by 2022 . To help accomplish this goal, the Workplace Charging Challenge encourages America's employers in all sectors of the economy to provide PEV charging access at their worksites.

The Workplace Charging Challenge provides resources, tools, and technical assistance to implement and manage workplace charging programs, and Challenge partners are nationally recognized for their sustainability efforts. For more information on workplace charging or becoming a partner, contact the Challenge atworkplacecharging@ee.doe.gov. 